\title{
Using dendrochronology to identify major ice storm events in oak forests of southwestern Virginia
}

\author{
Charles W. Lafon*, James H. Speer \\ Department of Geography, University of Tennessee, Burchfiel Geography Building, Room 304, Knoxville, \\ Tennessee 37996-0925, USA
}

\begin{abstract}
Major ice storms are significant forest disturbance agents and natural hazards in eastern North America. Studies of forest damage suggest that ice storm severity varies among topographic positions, but little climatic information is available to evaluate fine-scale variations in ice storm climatology. Our study assesses the utility of tree-ring analysis for identifying fine-scale spatial patterns and long-term temporal variations in the frequency of major ice storms. We looked for ice storm signals in tree-ring chronologies of chestnut oak Quercus prinus L. and black oak Q. velutina Lam. at 2 sites in southwestern Virginia that were affected by known ice storms in 1979 and 1994. Radial growth of these species exhibits a dual response to ice storm disturbance. Trees with substantial canopy loss show reduced radial growth for several years following an ice storm. Other trees display increased growth due to the loss of competitors. We identified thresholds of ring-width increase and decrease that distinguished ice storms from other events, permitting a preliminary attempt to reconstruct ice storm history at each of the 2 study sites. For our Gap Mountain site, ring-width chronologies spanning the period 1914-1998 record apparent signals of major ice storms in 1920, 1979, and 1994. For the Walker Mountain site, our results suggest that during the period 1901-1998 the stand was affected by major ice storms in 1918 and 1994. This study suggests that dendrochronology provides a promising method for understanding fine-scale spatial patterns of ice storm disturbance in hardwood forests.
\end{abstract}

KEY WORDS: Dendrochronology · Tree rings · Freezing rain · Ice storms · Forest disturbance · Appalachian

\section{INTRODUCTION}

Vegetation disturbances have important consequences for species composition and diversity (Loucks 1970, Huston 1994). In the forests of eastern North America, major ice storms produce heavy amounts of rain that freeze on tree surfaces, breaking limbs, bending or breaking boles, and toppling trees (Whitney \& Johnson 1984, Seischab et al. 1993). Canopy tree losses on the order of $50 \%$ are common in heavily damaged

*Present address: Department of Geography, Texas A\&M University, 3147 TAMU, College Station, Texas 77843-3147, USA. E-mail: clafon@geog.tamu.edu stands (Downs 1938, Seischab et al. 1993, Lafon et al. 1999). Where they occur frequently, ice storms represent one of the most significant agents of forest disturbance. They also disrupt traffic, damage utility lines, and cause other economic losses. Recent major ice storms in the southeastern and northeastern United States contributed to a number of deaths and caused several billion dollars in damage (Lott \& Sittel 1994, Lott et al. 1998).

The frequency and severity of ice storms vary spatially at several scales. Globally, ice storms occur most frequently in eastern North America, where conditions are favorable for the extreme air mass contrasts necessary for freezing rain to occur (Bennett 1959). Freezing 
rain typically results when warm, moist air is advected over a shallow subfreezing surface layer, creating an inversion (Stewart \& King 1987, Gay \& Davis 1993, Rauber et al. 1994). Raindrops falling from the warm layer aloft through the underlying cold air become supercooled and then freeze on impact to form a layer of ice (glaze) on trees, roads, utility lines, and other surfaces (Ahrens 1991, Gay \& Davis 1993). In clouds with few ice nuclei, a supercooled warm rain process may also produce freezing rain in the absence of an inversion (Huffman \& Norman 1988). Within North America, the midwestern and northeastern United States generally experience the highest frequencies of freezing rain (Bennett 1959, Eagleman 1983). The eastern Appalachian Mountains and the western Piedmont are also subject to frequent ice storms, a consequence of Appalachian cold air damming (Bennett 1959, Gay \& Davis 1993, Konrad 1998). This condition arises when cold air from a surface anticyclone situated over the Northeast is advected southwestward and becomes trapped against the eastern slopes of the mountains (Richwien 1980, Bell \& Bosart 1988). When air temperatures in the trapped surface air are below freezing, rain falling through this subfreezing air from a warmer layer above becomes supercooled and freezes on impact with surface objects (Michaels 1991).

Patterns of ice storm damage often exhibit pronounced topographic influences in hilly or mountainous terrain. In eastern North America, slopes facing east, north, northeast, or southeast appear especially susceptible to heavy ice accumulations (Rhoades 1918, Downs 1938, Spaulding \& Bratton 1946, Whitney \& Johnson 1984, Seischab et al. 1993, Lafon et al. 1999). Aspect-related differences may result from topographic effects on precipitation intensity (Sharon 1980, Poreh \& Mechrez 1984, Smith 1989, Lafon et al. 1999) or from influences of wind on twig surface temperatures and raindrop fall velocities (Lafon et al. 1999). In the Appalachian Mountains, elevational zonation in glaze damage is also common. Most evidence suggests that ridgetops are subject to more frequent ice storms or more severe ice storm damage than adjacent lowlands (Abell 1934, Carvell et al. 1957, Bennett 1959, Williams 1960, Anthes 1976, Nicholas \& Zedaker 1989, Konrad 1998), but results of Konrad (1998) imply that relationships between elevation and ice storm frequency vary regionally within the Appalachians. Analysis of such relationships is hindered by a lack of climatic data for mid- and high-elevation sites.

Despite observations of topographic variations in ice storm damage, little work has been conducted to quantify spatial patterns in ice storm frequency or severity at the scale of individual slopes or mountains. A dearth of pertinent climatic data hampers efforts to estimate patterns at such fine scales. First-order National
Weather Service (NWS) stations report weather type each hour, making it possible to identify the occurrence and duration of freezing rain events but not their magnitude. Gay \& Davis (1993) used data from firstorder stations to map patterns of freezing rain and sleet frequency in the southeastern U.S. However, firstorder weather station records do not permit quantitative assessments of the frequency of major, forest-damaging events, because ice accretion is not reported. Further, first-order stations are too sparsely distributed to permit resolution of topographic variations in ice storm frequency. Konrad (1998) used daily climatic data collected at cooperative weather stations in the Appalachians to estimate finer-scale patterns of ice storm frequency that show influences of major topographic features (e.g., Cumberland Plateau, Great Valley, Blue Ridge). Cooperative stations form a denser network than the first-order stations, but Konrad's technique still does not provide a way to identify landform-scale variations in the frequency of ice storm disturbance. Record-length constraints also limit the usefulness of instrumental climatic data. Climate records at most stations are only a few decades long, but recurrence-interval analyses for relatively infrequent events like major ice storms require longer data chronologies. Descriptive accounts such as newspaper articles provide longer records but do not furnish sufficiently detailed information for reconstructing long-term histories of ice storm disturbance at fine spatial scales.

We report here the results of a preliminary analysis designed to determine whether it is possible to distinguish a tree-ring signal resulting from ice storm disturbance in Appalachian hardwood forests. Discerning such a tree-ring signal would permit researchers to reconstruct the history of ice storm events that have affected a forest stand and to characterize landformscale spatial variations in ice storm climatology. Treering analysis, or dendrochronology, involves matching ring-width patterns between trees to develop a chronology of factors affecting tree growth. Dendrochronology provides a means to study patterns of climate at finer spatial scales than other records permit (Phipps 1982). It is also useful for extending temporal records of rainfall and temperature variations, droughts, forest fires, insect defoliations, and other events (Stahle et al. 1985, Baisan \& Swetnam 1990, Swetnam \& Betancourt 1990, Graumlich 1993, Swetnam \& Lynch 1993, Speer et al. 2001). Tree-ring analysis is commonly used in studies of fire history, because it is possible to date fire scars on trees that survive a blaze and to identify even-aged cohorts of earlysuccessional trees that colonize after a fire. Fine-scale spatial patterns of fire extent and fire frequency can be inferred by sampling trees growing on different topographic positions or dispersed throughout a watershed 
(Arno 1976, Romme \& Knight 1981, Baisan \& Swetnam 1990, Niklasson \& Granström 2000).

A few researchers have investigated relationships between ice storm occurrence and tree-ring width in conifers. Travis et al. (1989) and Travis \& Meentemeyer (1991) included ice storms in regression models they developed to predict ring width in loblolly pine Pinus taeda L. and shortleaf pine P. echinata Mill. in Georgia and South Carolina. The reduced growth resulting from ice damage accounted for 10-19\% of ring-width variance in addition to the $25-39 \%$ explained by standard temperature and precipitation variables. Travis \& Meentemeyer (1991) concluded that ice storm damage reduces radial growth only during the growing season immediately following the storm. This result may in part reflect the fact that trees showing no structural damage from ice were selected for the study. In contrast, Belanger et al. (1996) reported that loblolly pine damaged by a 1983 ice storm in Georgia still exhibited slower radial growth than adjacent undamaged trees when they studied the trees 5 yr later. Félin \& Rivest (1983) showed that ice storm damage contributed to reduced ring widths for several years in black spruce Picea mariana (Mill.) B.S.P. and balsam fir Abies balsamea (L.) Mill. in Quebec.

No previous research has been published specifically on the effects of ice storm disturbance on tree rings in hardwood species. Heavy ice accretion on tree branches causes severe canopy breakage among many hardwood species (Downs 1938, Carvell et al. 1957, Whitney \& Johnson 1984, Seischab et al. 1993). Such injuries may result in reduced radial growth following the storm. A common dendroecological application in hardwood forests is identification of periods of abruptly increased radial growth that follow canopy disturbance events (Lorimer 1980, Lorimer \& Frelich 1989). Such growth patterns generally indicate release of understory trees from competition with canopy individuals killed or damaged by a disturbance, but a release by itself does not reveal the cause of disturbance. Remaining canopy trees may also exhibit increased growth following canopy thinning, but their response is not as dramatic as that of understory trees (Lorimer \& Frelich 1989).

We hypothesized that, as in ice-damaged conifer stands and thinned hardwood forests, marked changes in radial growth would result from ice storm disturbance in a hardwood stand. To investigate this possibility, we conducted a dendrochronological study of chestnut oak Quercus prinus L. and black oak $Q$. velutina Lam. at 2 sites in southwestern Virginia, where major ice storms had occurred at known dates in recent years. These species are abundant over a wide range of topographic positions in upland forests of the Appalachian Mountains, and we hoped they could prove useful for studies of ice storm history. Oaks possess strong wood that may provide resistance to breakage, but severe damage (including canopy injury) has been reported for both these species (Whitney \& Johnson 1984, Seischab et al. 1993).

\section{STUDY AREA}

Two oak-dominated stands were selected, both on mountain slopes in southwestern Virginia. Oak forests are the primary cover type on relatively dry slopes in the southern and central Appalachians. Three recent ice storms caused major forest disturbance in southwestern Virginia. The first of these occurred on 20-21 January 1979. The other 2 occurred in 1994, one on 10-11 February and the other on 1-3 March. Data reported by NCDC (1979a,b, 1994a,b) imply that ice accreted to depths of $2.5 \mathrm{~cm}$ or more during all 3 events. Widespread forest damage occurred and was most severe on east- and southeast-facing slopes (Whitney \& Johnson 1984, Lafon et al. 1999). A full discussion of the meteorological events that produced the storms can be found in Lafon et al. (1999).

One study site is located on the southeast side of Gap Mountain, Montgomery County, Virginia, near the eastern end of the mountain at an elevation between 790 and $825 \mathrm{~m}$ (2600 to $2700 \mathrm{ft}$ ) (Fig. 1). Whitney \& Johnson (1984) described disturbance in this stand following the 1979 ice storm. Post-storm canopy cover in the stand was $67.0 \%$, significantly less than the $94.5 \%$ canopy cover found by Whitney \& Johnson in a neighboring undamaged oak forest. Numerous downed

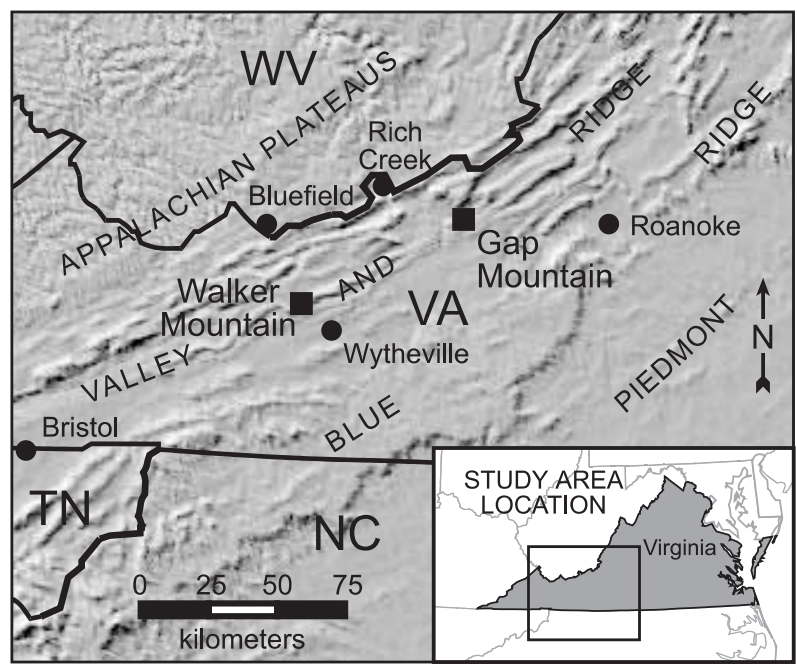

Fig. 1. Location of the Gap Mountain and Walker Mountain study sites in SW Virginia. Major towns and towns mentioned in the paper are also shown 
boles still remain on the forest floor and provide evidence of the heavy forest thinning that occurred throughout the stand in 1979. The storms of 1994 also affected the stand. Field observation of downed boles indicates that the most severe damage from the 1979 storm occurred at a lower elevation than the most severe 1994 damage. We focused on the portion of the stand affected by the 1979 event.

Our second study site is about $60 \mathrm{~km}$ southwest of the first one, on the southeast side of Walker Mountain, Bland County, Virginia, at an elevation between 850 and $915 \mathrm{~m} \mathrm{(2800} \mathrm{to} 3000 \mathrm{ft}$ ) (Fig. 1). Disturbance at this site was described by Lafon et al. (1999) after the forest was damaged by the ice storms of 1994. The ice storms created large interconnected canopy gaps. Post-storm canopy cover in this stand was $58 \%$. Stem basal area, a measure of tree abundance, declined $27 \%$ as a result of the 1994 ice storms (Lafon 2000), reflecting substantial thinning of the stand. Both the Gap Mountain and Walker Mountain sites are located in the Jefferson National Forest.

Patterns of ice storm frequency mapped by Konrad (1998) suggest that freezing rain events occur with moderate frequency in our study sites, relative to other parts of the southern and central Appalachians. Konrad's estimates imply a mean annual occurrence of 2.3 to 2.7 freezing rain events in our study area. Higher frequencies occur to the east (Blue Ridge and western Piedmont), where 3.0 to 3.4 events are estimated to occur annually. Estimated frequencies of freezing rain decline to the southwest of our study sites, to a low of about 1.0 event $\mathrm{yr}^{-1}$ in the Great Valley of eastern Tennessee.

\section{METHODS}

We cored 15 canopy trees at each of the 2 study sites during September 1998. Increment borers were used to collect 2 cores at breast height from opposite sides of each tree. We also cut cross-sections from 5 downed trees at each site, using a chain saw. The zones of the 1994 ice storm damage were evident from recently toppled boles and relatively fresh canopy damage. At Gap Mountain, the presence of toppled, decaying boles marked the zone in which heavy storm damage occurred in 1979. Trees were selected for sampling within the zones of major disturbance on the basis of tree age. We sampled older trees, regardless of damage level, to obtain the longest possible records.

We developed a master chronology (Stokes \& Smiley 1968) from 10 trees at each site and used significant marker rings from the master chronology to crossdate the remaining specimens. The rings were measured from each pair of cores and from 2 radial transects on each cross-section with a Velmex measuring stage accurate to $0.02 \mathrm{~mm}$. Then we ran the COFECHA program (Holmes 1986) on our results to verify and refine our dating. We used the ARSTAN program (Cook \& Holmes 1986) to standardize the individual series using a $50 \mathrm{yr}$ cubic smoothing spline. Each resultant ring-width index chronology has normalized variance and a mean of 1.0. Use of a $50 \mathrm{yr}$ smoothing spline retains $50 \%$ of the variance over a $50 \mathrm{yr}$ period and $99 \%$ of the variance over $16 \mathrm{yr}$, removing long-term trends while retaining virtually all annual- to decadalscale variation. Based on reported effects of ice storm damage on conifer ring-widths (Félin \& Rivest 1983, Belanger et al. 1996), we anticipated that any ice storm signal would be primarily subdecadal, so that a $50 \mathrm{yr}$ spline would be appropriate. We also used ARSTAN to average the paired chronologies from each tree into a single chronology.

In order to make any signal related to ice storms more visible, we first removed from our data sets as much of the noise related to background climate as possible. We conducted regression analyses to model the influence of climate on tree growth. ARSTAN was employed to generate for each species a single, regional-level growth chronology that was free of significant autocorrelation and that was suitable to use as a dependent variable in regression analysis. Independent variables for regression were monthly Palmer Drought Severity Index (PDSI) values for the 12 mo prior to September of the year of ring formation (NCDC 1999). PDSI is used frequently in dendrochronology and is often strongly correlated with tree-ring indices in eastern North America (Stahle et al. 1985, Jenkins \& Pallardy 1995). In our analyses, we used the average of PDSI for NOAA's Virginia Climate Divisions 5 and 6. Our study sites are located at relatively high elevations in the eastern part of Division 6. Division 5 is located immediately northeast of Division 6 , and we found that climate effects on tree growth were modeled best using the average PDSI for these divisions. We employed the stepwise regression procedure in our analyses. Significance levels for variable entry and retention were set to 0.05 and 0.10 , respectively.

PDSI exhibited significant relationships with growth of both species, although our sampling locations were not situated in extremely dry sites (e.g. rocky ridgetops), where trees would probably record a stronger climate signal (Fritts 1976). The following regression models were developed:

$$
\mathrm{CO}=0.996+0.02389 \mathrm{JUL}
$$

(adjusted $\mathrm{R}^{2}=0.121, \mathrm{SE}=0.100, F=15.054, \alpha<0.0005$ )

$$
\mathrm{BO}=1.013+0.02967 \mathrm{JUL}+0.01310 \mathrm{DEC} \_\mathrm{PY}
$$

(adjusted $\left.\mathrm{R}^{2}=0.182, \mathrm{SE}=0.118, F=12.332, \alpha<0.0005\right)$ 
For these equations, $\mathrm{CO}$ and $\mathrm{BO}$ are standardized ring width for chestnut oak and black oak respectively, JUL is July PDSI, and DEC_PY is PDSI for December of the year previous to the year of ring formation. We subtracted the climate signal (i.e., the modeled ring-width index predicted from the regression equations) from the ring-width index chronology for each tree to yield a residual 'climate-free' chronology whose variability is relatively disassociated from background climate and therefore more clearly signals other factors that affect ring width. We added 1.0 to each residual chronology, giving each 'climate-free' chronology a mean of approximately 1.0 .

To allow identification of earlier ice storms, in addition to those of 1979 and 1994, we compiled a list of significant ice storms that may have affected our study sites during the period covered by our chronologies. We obtained information on these storms from the National Climatic Data Center (NCDC) publication Storm Data and Unusual Weather Phenomena. This monthly publication and its predecessors provide qualitative state-by-state descriptions of major weather events, including ice storms, back to 1914. We noted records of ice storms or heavy, wet snowstorms that caused damage to trees or utility lines. Similar information was obtained for the period 1900-1914 from monthly weather descriptions published in Monthly Weather Review. Storm reports are available in pre1900 issues of Monthly Weather Review, but the records are too brief to be useful. We verified the occurrence of all storms by searching for storm descriptions on the appropriate dates in The Roanoke [Virginia] Times and World News. Qualitative descriptions, particularly the sketchy reports of early years, are often inadequate for determining spatial extent of storm damage, but we recorded all events that may have affected our study sites.

\section{RESULTS}

Analysis of climate-free ring-width index chronologies revealed a bipartite ice storm signal. Following ice storm disturbance, radial growth declined in some trees but increased in others. The climate-free ringwidth indices are graphed in Figs 2 \& 3. Series ending before 1998 are from cross-sections cut from trees toppled during one of the ice storms. Also, winds from remnants of Hurricane Hugo downed one of our sample trees in 1989 (chronology P, Fig. 3).

Some chestnut oak chronologies (especially chronologies $\mathrm{C}$ and H, Fig. 2) from the Gap Mountain site record decreased growth for 1979, the year of a major ice storm, but long periods of growth suppression are not evident in this species. Several chestnut oak chronologies indicate that radial growth increased for a few yr after the 1979 ice storm. The 1979 storm is not recorded, at least as a major event, at Walker Mountain (Fig. 3). Decreases and increases in radial growth following the 1994 storms are evident among chestnut oak at both study sites, particularly Walker Mountain.

Among the black oaks, 2 at Gap Mountain had decade-long growth suppressions beginning in 1979 (chronologies L and R, Fig. 2), and several experienced decreased growth during the year of the storm. The 1994 storms triggered growth decreases and increases in several black oak trees (Figs 2 \& 3), but the 1994 signal is not as pronounced as that for the 1979 event. Black oak shows a stronger signal than chestnut oak for the 1994 storms at Gap Mountain (Fig. 2). However, at Walker Mountain black oak records a weaker signal of the 1994 storms than chestnut oak (Fig. 3). Visual inspection of our samples clearly reveals these patterns of suppression and release following the 1979 and 1994 ice storms.

To quantify objectively the dual pattern of suppression and release that appeared to constitute the ice storm signal in our results, we compared, for each tree, the climate-free ring-width index for each year to the mean for the previous 5 yr. We arbitrarily defined a significant decrease as one in which climate-free ringwidth index declines at least $40 \%$, and a significant increase as an enlargement of at least $50 \%$ over the mean for the previous 5 yr. These thresholds capture the signals of the 1979 and 1994 ice storms but exclude most of the noise during the same period that is not associated with known ice storms. Fig. 4 graphs the percent of trees experiencing significant growth decrease ('percent suppressed') and increase ('percent released') each year. Significant changes in growth associated with the 1979 and 1994 ice storms show clearly. Significant growth reductions occurred in at least $11 \%$ of all trees during the growing season immediately following the 1979 and 1994 storms. Examination of Figs 2-4 reveals that initiation of significant growth increase may lag the disturbance by a year. This pattern may constitute an additional diagnostic tool for identifying ice storms in tree-ring chronologies.

Climatic records indicate that several other ice storms and heavy snowstorms occurred in the vicinity of the study sites during the years covered by our treering chronologies (Table 1). The graphs in Fig. 4, which encompass the period covered by 10 or more parallel chronologies, show potential responses to several known events. It appears that the January 1918 and November 1920 ice storms are clearly recorded in the Walker Mountain and Gap Mountain chronologies, respectively. Other events, such as a 1911 snowstorm or ice storm, a 1925 ice storm, or the 1934 snowstorm, 

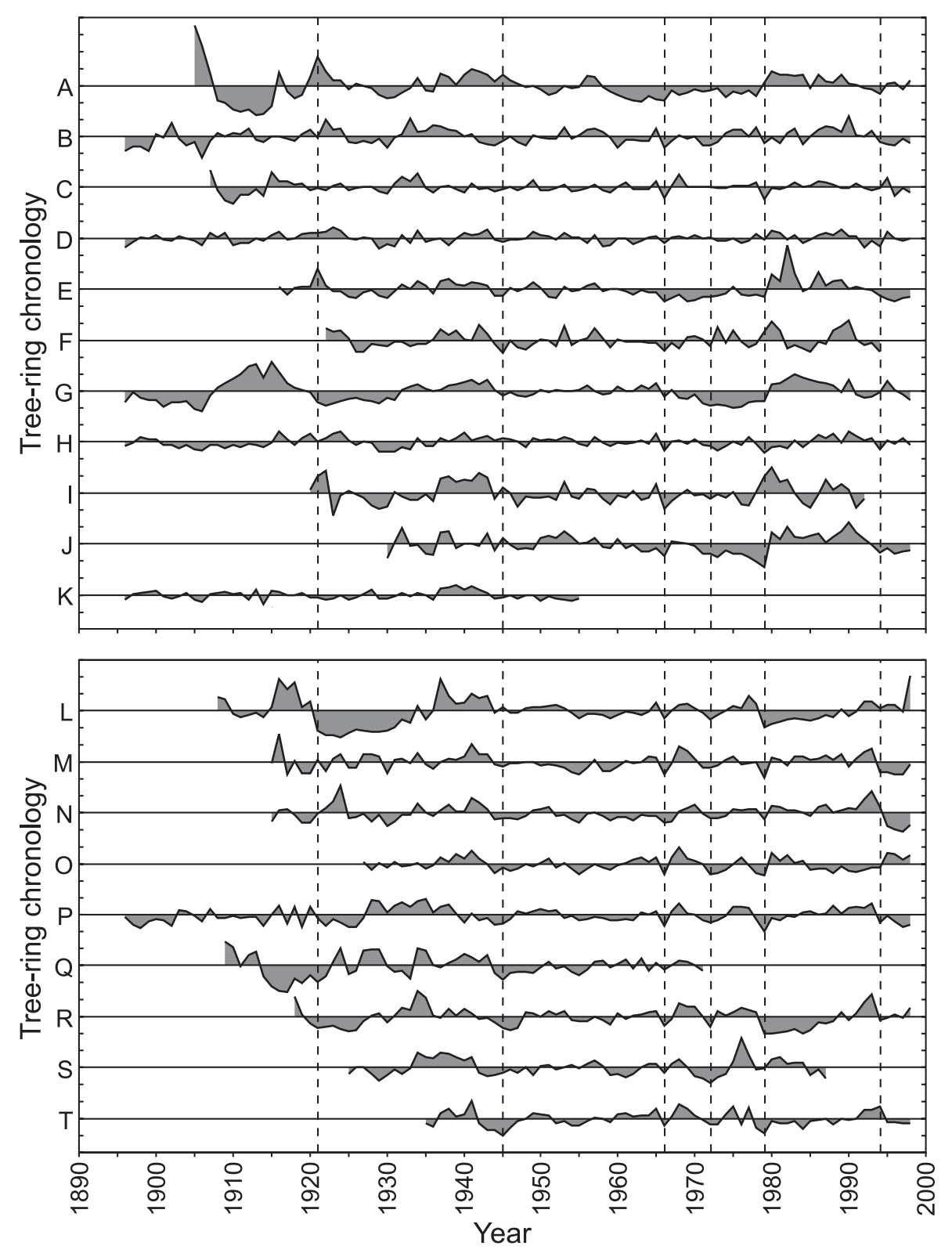

Fig. 2. Climate-free ring-width index chronologies for chestnut oak (top) and black oak (bottom) at the Gap Mountain site, 1896-1998. Each chronology has a mean of 1, represented by the horizontal line along which the chronology is graphed. Tic marks on the $y$-axis are in increments of 0.5 and therefore represent ring-width index values of \pm 0.5 relative to the mean. Dashed lines indicate known or potential ice storm years during which $\geq 10 \%$ of trees showed significant growth reduction

correspond to possible signals as well. There are no indications that the major ice storms of 1978 or 1998 affected either site. The tree-ring chronologies record a few possible signals not associated with known events in Table 1, e.g., the reduced growth of 1945 and 1966 at Gap Mountain (Fig. 4A). We did not interpret the apparent suppression-release pattern at the beginning of the Gap Mountain chronology, because the signal begins in the pre-1914 period, for which our sample size is small.
Examining signal duration may help distinguish ice storm signals from those caused by other events. Fig. 4 does not show the duration of reduced or increased growth. This is because each ring-width index is compared to the mean for the previous $5 \mathrm{yr}$, and $5 \mathrm{yr}$ into a period of suppression (or release) the ring would be compared only to other suppressed (or released) rings. To determine signal duration, it is necessary to compare growth during post-storm years only to that occurring prior to the storm. 

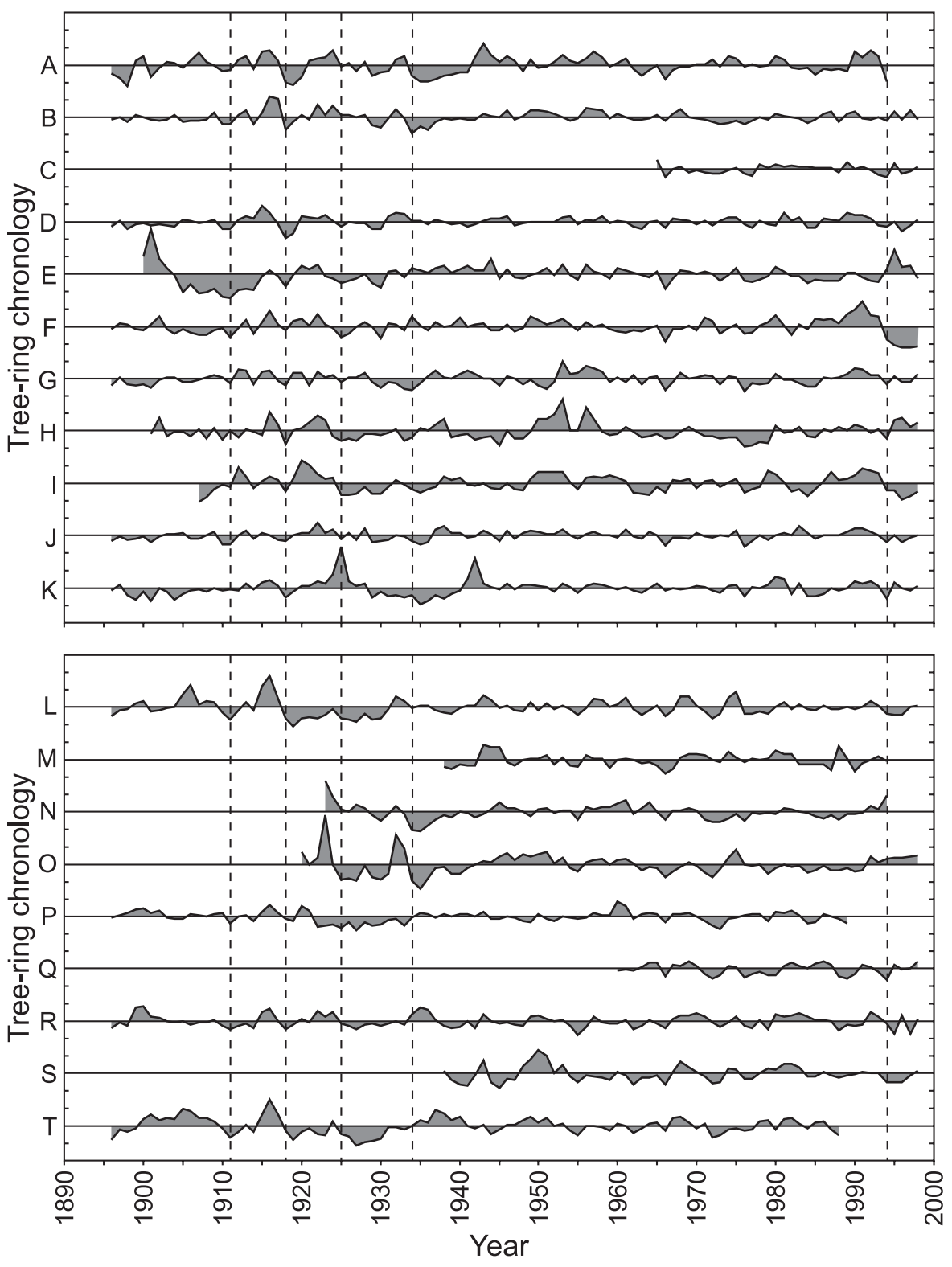

Fig. 3. Ring-width index chronologies for chestnut oak (top) and black oak (bottom) at the Walker Mountain site, $1896-1998$. Axis-scaling and dashed lines are as in Fig. 2

We therefore examined signal duration for all potential ice storm signals recorded in our climate-free ringwidth index chronologies. We defined a potential ice storm year as a year in which significant growth reduction was initiated in at least $10 \%$ of trees. This $10 \%$ threshold captures any growth reduction similar to those resulting from the 1979 and 1994 ice storms. Such growth reductions were initiated 6 times in the Gap Mountain series and 5 times in the Walker Mountain series. The initial year of each event is labeled as a potential ice storm year in Fig. 4 and is indicated by a dashed line in Figs $2 \& 3$. A year was not included as a potential ice storm year if growth declines observed that year were initiated during a previous year. For example, 1980 was not identified as a potential ice storm year for Gap Mountain, even though more than $10 \%$ of trees showed significant growth reduction that year. Growth declines for these trees began in 1979, the year of the storm, and continued into 1980.

Graphs in Figs $5 \& 6$ convey the duration of these signals. To create the graphs, we identified the individual trees that sustained significant growth reduction ( $\geq 40 \%$ decline) during each of the potential ice storm years. To capture lagged responses we also 

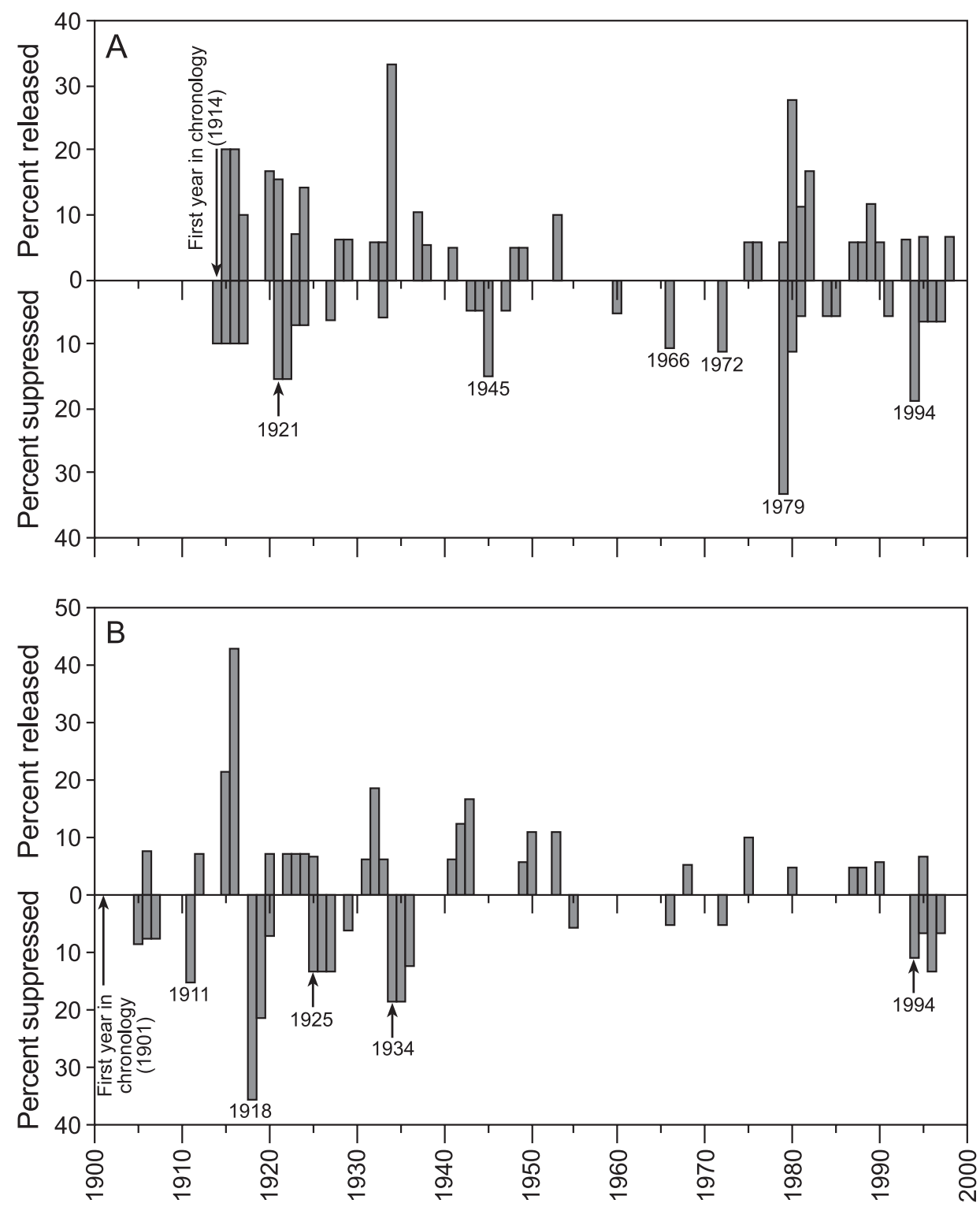

Fig. 4. Percent of trees exhibiting significant growth decrease (suppression) or increase (release) each year for (A) Gap Mountain and (B) Walker Mountain. These graphs cover the period with at least 10 parallel chronologies available. Known and potential ice storm years, during which $\geq 10 \%$ of all trees showed significant growth reduction, are labeled

identified trees in which significant growth reduction began the year following the potential ice storm year. We tracked the growth of each of these trees during subsequent years, tallying for each year how many of these trees experienced growth reductions of $\geq 40 \%$ relative to the $5 \mathrm{yr}$ prior to the potential ice storm. We continued tracking the trees as they recovered, until none of them showed significantly reduced growth. Similarly, we determined which trees showed significant growth increase $(\geq 50 \%$ increase) beginning in the potential storm year or in 1 of the 2 succeeding years. We tracked their subsequent growth until none of them maintained significantly increased growth in relation to the mean for the $5 \mathrm{yr}$ prior to the potential ice storm.

The 1979 and 1994 ice storm signals (Figs 5E,F \& 6E) are characterized by the bipartite signal of long periods (at least $5 \mathrm{yr}$ ) of significantly reduced growth in some trees and by significant growth increase beginning within $1 \mathrm{yr}$ of the ice storm year in other trees. However, the pattern of increased growth associated with the 1994 storms is less pronounced than that following the 1979 event. In the Gap Mountain chronologies, the 1921 signal is the only pre-1979 signal exhibiting the occurrence both of long suppression and of the initiation of significant growth increase 
Table 1. Record of ice storms and heavy, wet snowstorms that may have affected our study area during the period 1900-1998. The year assigned to each event is the first growing season after the storm occurred. Sources of information are abbreviated as follows: MWR = Monthly Weather Review, RT = The Roanoke Times and World News, SD = Storm Data and Unusual Weather Phenomena or predecessor

\begin{tabular}{|c|c|}
\hline Year & Remarks \\
\hline 1906 & Ice damage to orchards in VA and NC in Jan 1906, but damage may have been restricted to the Piedmont (MWR) \\
\hline 1911 & $\begin{array}{l}\text { Four inches of sleet in Wytheville on Mar 7, } 1911 \text { (MWR). Heavy snow in Roanoke, but snow melted rapidly as it fell } \\
\text { and only accumulated } 2 \text { inches (RT) }\end{array}$ \\
\hline 1918 & $\begin{array}{l}\text { Heavy 'sleet' storms throughout VA on Jan 11-15, 1918, and Jan 27-30, } 1918 \text { (SD). RT reports most of SE suffered } \\
\text { from sleet or glaze, but no information specific to western VA }\end{array}$ \\
\hline 1920 & Several moderate ice storms in VA in Jan 1920 (SD) \\
\hline 1921 & Major ice storm in western VA on Nov 14-16, 1920 (SD, RT) \\
\hline 1925 & $\begin{array}{l}\text { Ice storm on Jan 1-3, } 1925 \text { caused heavy tree damage in central VA and power line damage over most of state (SD, } \\
\text { RT) }\end{array}$ \\
\hline 1932 & Heavy snow on Mar 8, 1932 damaged telegraph lines, mostly north and east of Roanoke (SD, RT) \\
\hline 1934 & $\begin{array}{l}\text { Heavy snow in SW VA on Feb 25-26, 1934, accompanied by sleet, freezing rain, and thunderstorms, caused timber } \\
\text { and power line damage (SD, RT) }\end{array}$ \\
\hline 1962 & Wet snow on Oct 20,1961 damaged trees and power lines in parts of SW VA (SD). Not so heavy at our study sites (RT) \\
\hline 1969 & $\begin{array}{l}\text { Moderate to major ice storm on Jan 20-21, 1969, caused considerable damage to trees and utility lines at high eleva- } \\
\text { tions. Rain at low elevations, snow in Shenandoah Valley (SD) }\end{array}$ \\
\hline 1971 & $\begin{array}{l}\text { Heavy snow on Apr 6-7, 1971, damaged trees and power lines in western VA (SD), but RT does not mention line dam- } \\
\text { age }\end{array}$ \\
\hline 1974 & Heavy snow Dec 10, 1973, damaged power lines, mostly near Rich Creek (SD, RT) \\
\hline 1975 & $\begin{array}{l}\text { Heavy snow, sleet, rain, and wind damaged trees and power lines in western VA on Dec 1-2, 1974. Most damage } \\
\text { apparently east of our sites, toward Roanoke (SD, RT) }\end{array}$ \\
\hline 1978 & $\begin{array}{l}\text { Major ice storm in western VA on Mar 27, 1978. Heavy damage was restricted to elevations above } 915 \mathrm{~m} \text { ( } 3000 \mathrm{ft})(\mathrm{SD} \text {, } \\
\text { RT) }\end{array}$ \\
\hline 1979 & Major ice storm on Jan 20-21, 1979 (SD, RT) \\
\hline 1984 & $\begin{array}{l}\text { Major ice storm on Dec 21-22, 1983, in western, northern, and central VA. Much power line damage in Roanoke vicin- } \\
\text { ity, less to the west (SD, RT). Wet snow on Feb. 23, 1984, damaged trees and power lines near Bluefield (SD, RT) }\end{array}$ \\
\hline 1994 & Major ice storms on Feb 10-11, 1994, and Mar 1-3, 1994 (SD, RT) \\
\hline 1998 & $\begin{array}{l}\text { Major ice storm on Feb 4-6, 1998, caused heavy forest damage above } 850 \mathrm{~m} \text { ( } 2800 \mathrm{ft} \text { ) in western VA, mainly east of } \\
\text { our study sites (SD, RT) }\end{array}$ \\
\hline
\end{tabular}

within 1 yr of the potential storm year (Fig. 5A). This signal appears to be associated with the November 1920 ice storm (Table 1). Among the pre-1994 signals identified for Walker Mountain, the 1918 signal (Fig. 6B) includes a long period of suppression and a lagged growth increase that may indicate a response to ice storms of January 1918 (Table 1). One difference between this signal and those associated with known recent ice storms is that significant growth increase does not begin until 2 yr after the year of the potential storm. The 1925 and 1934 signals (Fig. 6C,D) resemble signals of known ice storms but show shorter periods of growth reduction. The 1911 signal may be associated with a March 1911 'sleet' storm (Table 1), but it does not show the long suppression that characterizes the signals of known major ice storms. Examination of precipitation and drought records for our study area (United States Historic Climate Network [USHCN] 1998, National Climatic Data Center [NCDC] 2001) reveals that some of the signals of reduced growth in Figs 5 \& 6 may have resulted from drought, although subtracting the climate signal from the series has reduced the magnitude of the drought signal. Each graph is labeled according to the event with which it appears to be associated, based on climate records.

\section{DISCUSSION}

\subsection{Ice storm signal}

The ice storm signal consists of opposing patterns. First, severe canopy damage results in the loss of support structure for leaves, causing a sharp decline in radial growth, which remains low for several years. These results are similar to those reported for icedamaged pines in the Appalachian Piedmont (Belanger et al. 1996) and for spruce and fir in Quebec (Félin \& Rivest 1983). Radial growth is particularly sensitive to stress or injury, because stem growth is a low priority for allocation of resources within a tree (Waring \& Pitman 1985, Pedersen 1998). Second, trees 

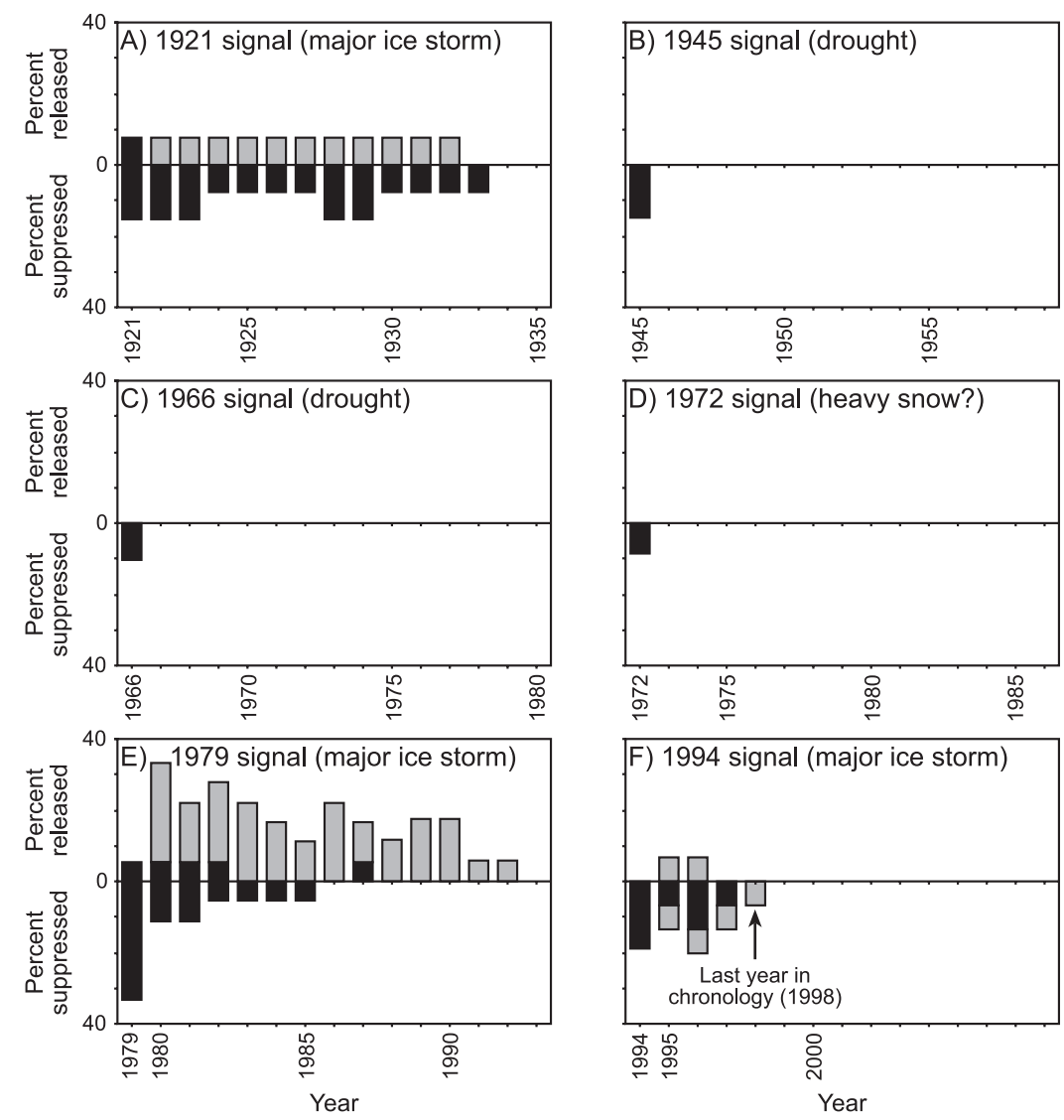

Fig. 5. Percent of trees at Gap Mountain exhibiting significant growth decrease (suppression) or increase (release) relative to the $5 \mathrm{yr}$ period prior to the year of the signal. Black bars indicate trees in which significant growth change occurred during the year of the signal. Stippled bars show trees in which significant growth response lagged the initial year of the signal by $1 \mathrm{yr}$. Each graph is labeled according to the event with which it appears to be associated others are affected little (Whitney \& Johnson 1984).

Tree-ring chronologies from eastern temperate forests are typically noisy with respect to any particular signal of interest, but our results indicate that ring-width changes resulting from ice storm disturbance are among the strongest signals in our chronologies, permitting the establishment of suppression and release thresholds for identifying potential signals of earlier ice storms. Signal duration further distinguishes ice storms from other events. A long period of reduced growth is the most consistent signal of ice storm disturbance in our tree-ring chronologies, but evidence of pronounced growth increase is also useful for verifying the occurrence of an ice storm.

The thresholds we used may not be appropriate for all species and study sites. Trees growing in highly productive stands, for example, may show stronger release patterns and more rapid rates of recovery from injury. Nonetheless, it is likely that a similar set of criteria could be developed to distinguish ice storms from other events, which would create considerably different ratios of suppressed to released trees. Windstorms, for example, may trigger release but rarely suppression, whereas drought reduces growth of nearly all trees.

sustaining less damage show increased radial growth following an ice storm. This signal is a response to release from competition with neighboring trees that were damaged or removed, and is a typical growth pattern in stands thinned by disturbance (Lorimer 1980, Lorimer \& Frelich 1989). The degree of forest thinning and canopy damage caused by the 1979 and 1994 ice storms resulted in considerable increases in light availability. Opposing growth responses probably offset each other in some damaged trees, weakening the ice storm signal. For example, at Walker Mountain, the 1994 ice storms broke out approximately half the canopy of tree $\mathrm{R}$, but tree rings provide little evidence of the damage (Fig. 3). The dual signal has not been reported in dendrochronological studies of ice storms in conifers. However, it is probably common in hardwoods, because tree damage within hardwood stands is often highly varied. Some trees sustain severe canopy breakage, some are toppled or broken, and
The widespread, heavy canopy damage characteristic of severe ice storm disturbance does not appear common in wind-damaged forests, except in the case of extreme winds associated with tornadoes and the most powerful hurricanes (Reilly 1991, Whigham et al. 1991). Hurricane damage is reported to produce a dual tree-ring signal, similar to ice storms, in coastal sites that experience winds strong enough to strip limbs from trees (Doyle \& Gorham 1996, Reams \& van Deusen 1996). However, in inland forests such wind speeds rarely occur. Severe canopy damage is much less common than uprooting (Foster 1988, Greenberg $\&$ McNab 1998), and growth release appears to be the predominant tree-ring signal (Merrens \& Peart 1992). Catastrophic disturbance resulting from downbursts or other severe thunderstorm winds is typically in the 1983, United States Forest Service [USFS] 1999). Bent or snapped trees that recover from wind damage may form of toppling, bending, or snapping (Dunn et al. 


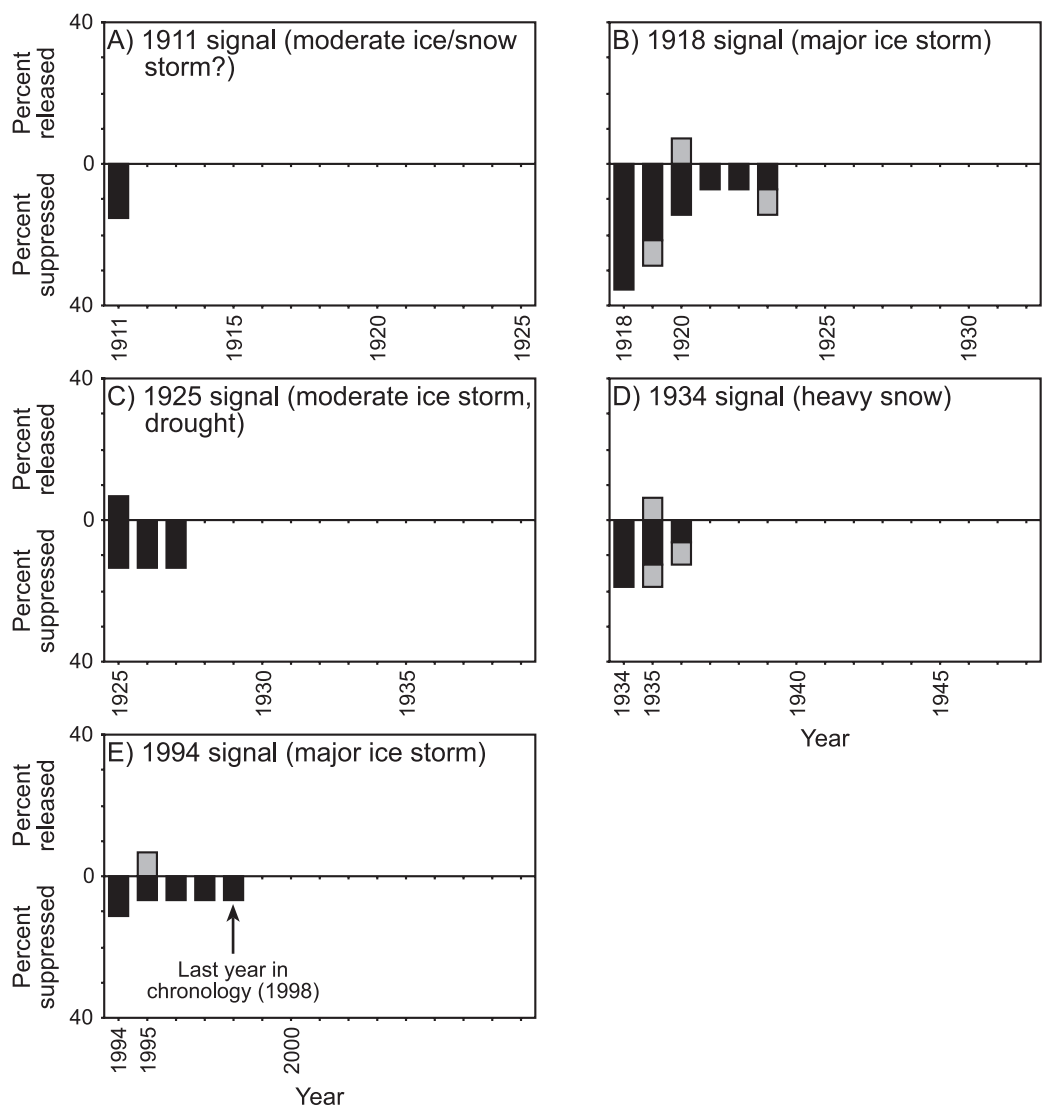

Fig. 6. Percent of trees at Walker Mountain exhibiting significant growth decrease (suppression) or increase (release) relative to the $5 \mathrm{yr}$ period prior to the year of the signal. Patterns are as in Fig. 5, with the addition that stippled bars indicate trees in which significant growth response lagged the initial year of the signal by $2 \mathrm{yr}$

exhibit a period of suppression following the storm, but release is likely to be the predominant signal in such a stand. Literature on tornado disturbance is limited, but it is clear that a variety of damage types, including crown damage, can result (Held \& Winstead 1976, Glitzenstein \& Harcombe 1988, Peterson \& Rebertus 1997). Severe canopy damage does not appear to be as widespread as in an ice-damaged forest, however. In any case, tornadoes are infrequent in the Appalachians (Kelly et al. 1978, Eagleman 1983, Leathers 1993). Further, spatial patterns of ice storm disturbance across a landscape differ from those caused by windstorms. An ice storm typically affects specific elevation zones over a broad area, whereas tornadoes and downbursts are local rather than regional and devastate long, straight, narrow corridors of forest oriented west-to-east or southwest-to-northeast (Glitzenstein \& Harcombe 1988, Wilkinson 1993). These differences in disturbance pattern should permit researchers to distinguish between the 2 disturbance types. Clearly, the influence of wind on Appalachian forests merits fur- ther research. It would be instructive to conduct a dendrochronological study in an Appalachian oak forest affected by a major windstorm to characterize the signal produced by such an event.

Wet snow can accumulate heavily on tree limbs and may produce an 'ice storm' signal in Appalachian forests. Forest damage resulting from a February 4, 1998, snowstorm resembled moderate ice storm damage in forests on the Cumberland Plateau of Tennessee (C.W.L. pers. obs.). The storm chronology presented in Table 1 includes several such events, including a 1934 storm that may have produced the 1934 signal in Walker Mountain chronologies. However, the strongest signals (1918, 1921, 1979, and 1994) appear to be associated with major ice storms.

Severe drought can substantially reduce growth, and a few of the treering signals graphed in Figs 5 \& 6 are probably associated with drought. However, drought signals are limited in duration and are therefore not confused easily with signals of major ice storms. Nonetheless, a drought signal may last up to 5 yr (Lorimer \& Frelich 1989). Subtracting the climate signal diminishes the drought signal, making it unlikely that a drought would be confused with an ice storm. Under unusual circumstances, a drought signal could conceivably be mistaken for an ice storm signal if climate subtraction were not performed. For example, a severe drought lasting several years, combined with a major windstorm, might produce a dual signal of suppression and release. However, the landscape pattern of a drought-windstorm combination would undoubtedly differ from that of an ice storm. Another possibility is that drought combined with a moderate-intensity ice storm might amplify the signal that would result from either event alone. Travis et al. (1990) reported that ice-damaged loblolly pine showed greater response to climatic stress than undamaged trees. Such a combination may be responsible for the period of reduced growth recorded at Walker Mountain following the 1925 ice storm and 1925-1926 drought (Table 1, Fig. 6C).

One consideration is that the signature of ice storm disturbance may change over time within a forest stand, as trees mature and change in susceptibility to particular types of ice damage. Trees become more 
susceptible to canopy damage as they age (Downs 1938, Lafon 2000), a pattern that may cause difficulty in detection of signals for ice storms that occurred soon after logging or farmland abandonment in the early twentieth century, when some of the trees we sampled were quite young. Nonetheless, sufficient numbers of trees were damaged by the 1918 and 1920 events to generate strong suppression patterns despite the younger tree ages. Many of the trees, at 10 to $30 \mathrm{~cm}$ in diameter in 1920, were large enough to be damaged by ice storms. Stems of young trees are especially susceptible to bending and snapping (Downs 1938, Lafon 2000), and trees that survive such an event may show years of reduced radial growth. Young tree canopies are also damaged when larger trees or branches fall on them. It will be important in future research to locate older forests that were not logged heavily in the early 1900s.

Canopy and understory trees respond differently to enhanced light levels after a disturbance. Radial growth of understory trees previously suppressed by deep shade often increases by $100 \%$ or more, but canopy trees respond less dramatically (Lorimer \& Frelich 1989). This may help explain differences between the 1979 and 1994 signals at Gap Mountain. Although the 1979 storm damaged several of our sample trees, the growth declines typically persisted for only a year or two (Figs $2 \& 5 \mathrm{E}$ ). The predominant pattern is one of increased growth. This pattern suggests that growth in many of the sampled trees was suppressed by shade from taller individuals prior to the 1979 storm. Following this disturbance, the smaller trees grew rapidly and gained canopy positions. Hence, by 1994 they were more vulnerable to damage and less responsive to increased light. Differences in response to the 1979 and 1994 storms probably also reflect spatial variations in damage severity. The 1994 storm caused more damage at elevations slightly above our sampling site, which was in the zone of severe damage from the 1979 storm. Despite variations in the signal produced by the different storms, all the major storm signals were similar enough to be distinguished from other ring-width patterns, indicating that comparable and identifiable ice storm signals are produced at different stand ages.

\subsection{Directions for future research}

Our results suggest that dendrochronology merits attention as a technique for studying landform-scale spatial variations in ice storm damage and for extending the length of the ice storm record. This study also points toward directions for additional work. First, response to disturbance varies greatly between trees-from long suppressions, to little change in growth, to major release-and this complex signal is more difficult to interpret than a simpler one, such as uniform suppression. Collecting a greater number of samples per study site would help clarify this varied response and would also help to overcome noise associated with unrelated events that affect individual trees but not the entire stand.

Second, it appears that some species may be better recorders of ice storm disturbance than others. Several additional oak species, as well as pignut hickory Carya glabra (Mill.) Sweet and yellow-poplar Liriodendron tulipifera L., are widely distributed in Appalachian hardwood forests and may be useful in research on ice storm climatology. Variations in response among stands of different ages and productivity levels merit attention as well.

The results of our preliminary study suggest that during the 1914-1998 period the Gap Mountain site was affected by major ice storms during 3 winters 1920-1921, 1979, and 1994 - the last of which had 2 events. During the 1901-1998 period, Walker Mountain forests apparently were affected by major ice storms in 1918 and 1994. Weaker signals, such as the 1925 and 1934 signals for Walker Mountain, may reflect the occurrence of moderate-intensity ice storms or heavy snowstorms. It is unclear whether the 1911 signal corresponds to the 1911 'sleet' storm recorded in Table 1. Perhaps the event was characterized by mixed precipitation that caused some tree damage but not a major disturbance. Our dendrochronological evidence and the independent storm records imply that the frequency of major ice storms varied temporally over the twentieth century. It appears that no major ice storms occurred in this region between the 1920s and the late 1960s but that several occurred during the last $20 \mathrm{yr}$. Additional sampling is needed to determine whether other ice storms or heavy snowstorms are recorded in our study area. In particular, it would be useful to locate older trees that may provide records of ice storms occurring during the 1800s and early 1900s and to establish chronologies for stands growing on sites of different elevation, aspect, and slope.

\section{SUMMARY}

Major ice storms cause widespread forest disturbance and disrupt human society. Studies of forest disturbance indicate that ice storm severity varies among topographic positions. Certain aspects and elevation zones may be particularly prone to ice storm damage. Instrumental climatic data are not suitable for assessing these landform-scale patterns, but ice storms produce a tree-ring signal that shows promise for analyzing fine-scale spatial variations and for extending the 
length of the ice storm record. Previous dendrochronological studies of ice storm effects on coniferous species demonstrated that canopy damage from ice storms contributes to reduced ring width following the event. In this study we found a dual signal in chestnut oak and black oak that consists of growth reductions and increases following an ice storm. Growth reductions result from canopy damage, and growth increases reflect the response of trees to reduced competition with other individuals that have been broken or killed.

The dual signal differentiates ice storm damage from other types of disturbance in Appalachian forests. Like many tree-ring signals in eastern forests, the signal is relatively subtle. However, the results of this study demonstrate that the occurrence of major ice storms can be identified quantitatively using thresholds and durations of ring-width decrease and increase. More investigation is needed to determine whether other species are more suitable for ice storm research and to document how the ice storm signal differs among forests of different ages and productivity levels. Successful resolution of these issues will enhance the study of fine-scale spatial patterns and long-term temporal variations in the climatology of major ice storms.

Acknowledgements. This research was supported by the Environmental Protection Agency STAR grant EPA R82515701-1 and the Dendroclimatology Laboratory, Department of Geography, University of Tennessee. Katherine Becksvoort, Evan Hart, Sally Horn, and Ken Orvis assisted in the field, helped us mount and sand cores, and provided useful comments. Henri Grissino-Mayer, Carol Harden, and Michael Huston also provided advice. The comments of Chip Konrad and 2 anonymous reviewers helped us improve the paper. We thank the Jefferson National Forest for granting permission to collect samples.

\section{LITERATURE CITED}

Abell CA (1934) Influence of glaze storms upon hardwood forests in the southern Appalachians. J For 32:35-37

Ahrens CD (1991) Meteorology today: an introduction to weather, climate, and the environment, 4th edn. West, St. Paul, MN

Anthes RA (1976) Variations in temperatures and freezing conditions between mountaintops and valleys in central Pennsylvania. Weatherwise 29:178-183

Arno SF (1976) The historical role of rire on the Bitterroot National Forest. US Forest Service Research Paper INT187, Ogden, UT

Baisan CH, Swetnam TW (1990) Fire history on a desert mountain range: Rincon Mountain Wilderness, Arizona, U.S.A. Can J For Res 20:1559-1569

Belanger RP, Godbee JF, Anderson RL, Paul JT (1996) Ice damage in thinned and nonthinned loblolly pine plantations infested with fusiform rust. South J Appl For 20:136-142

Bell GD, Bosart LF (1988) Appalachian cold-air damming. Mon Weather Rev 116:137-161

Bennett I (1959) Glaze: its meteorology and climatology, geo- graphical distribution, and economic effects. US Army, Quartermaster Research and Engineering Command Technical Report EP-105, Natick, MA

Carvell KL, Tryon EH, True RP (1957) Effects of glaze on the development of Appalachian hardwoods. J For 55: $130-132$

Cook ER, Holmes RL (1986) User's manual for program ARSTAN. In: Holmes RL, Adams RK, Fritts HC (eds) Treering chronologies of western North America: California, eastern Oregon, and northern Great Basin. Chronology Series 6. Laboratory of Tree-Ring Research, University of Arizona, Tucson, p 50-56

Downs AA (1938) Glaze damage in the birch-beech-maplehemlock type of Pennsylvania and New York. J For 36:63-70

Doyle TW, Gorham LE (1996) Detecting hurricane impact and recovery from tree rings. Radiocarbon 14:405-412

Dunn CP, Guntenspergen GR, Dorney JR (1983) Catastrophic wind disturbance in an old-growth hemlock-hardwood forest, Wisconsin. Can J Bot 61:211-217

Eagleman JR (1983) Severe and unusual weather. Van Nostrand Reinhold, New York

Félin B, Rivest J (1983) An application of dendrochronology to the determination of the recurrence of severe ice storms. In: Atmospheric icing of structures: proceedings of first international workshop: 1-3 June 1982, Hanover, NH. CRREL Special Report 83-17. US Army Corps of Engineers, Cold Regions Research and Engineering Laboratory, Hanover, NH, p 217-224

Foster DR (1988) Species and stand response to catastrophic wind in central New England, U.S.A. J Ecol 76:135-151

Fritts HC (1976) Tree rings and climate. Academic Press, London

Gay DA, Davis RE (1993) Freezing rain and sleet climatology of the southeastern USA. Clim Res 3:209-220

Glitzenstein JS, Harcombe PA (1988) Effects of the December 1983 tornado on forest vegetation of the Big Thicket, southeast Texas, U.S.A. For Ecol Manage 25:269-290

Graumlich LJ (1993) A 1000-year record of temperature and precipitation in the Sierra Nevada. Quat Res 39:249-255

Greenberg CH, McNab WH (1998) Forest disturbance in hurricane-related downbursts in the Appalachian Mountains of North Carolina. For Ecol Manage 104:179-191

Held ME, Winstead JE (1976) Structure and composition of a climax forest system in Boone County, Kentucky. Trans Ky Acad Sci 37:57-67

Holmes RL (1986) Users manual for program COFECHA. In: Holmes RL, Adams RK, Fritts HC (eds) Tree-ring chronologies of western North America: California, eastern Oregon, and northern Great Basin. Chronology Series 6. Laboratory of Tree-Ring Research, University of Arizona, Tucson, p 41-49

Huffman GJ, Norman GA (1988) The supercooled warm rain process and the specification of freezing precipitation. Mon Weather Rev 116:2172-2182

Huston MA (1994) Biological diversity: the coexistence of species on changing landscapes. Cambridge University Press, Cambridge

Jenkins MA, Pallardy SG (1995) The influence of drought on red oak group species growth and mortality in the Missouri Ozarks. Can J For Res 25:1119-1127

Kelly DL, Schaefer JT, McNulty RP, Doswell CA III (1978) An augmented tornado climatology. Mon Weather Rev 106: $1172-1183$

Konrad CE II (1998) An empirical approach for delineating fine scaled spatial patterns of freezing rain in the Appalachian region of the USA. Clim Res 10:217-227 
Lafon CW (2000) Patterns and consequences of ice storms in forested Appalachian landscapes. PhD thesis, University of Tennessee, Knoxville

Lafon CW, Graybeal DY, Orvis KH (1999) Patterns of ice accumulation and forest disturbance during two ice storms in southwestern Virginia. Phys Geogr 20:97-115

Leathers DJ (1993) A synoptic climatology of northeastern United States tornadoes. Phys Geogr 14:171-190

Lorimer CG (1980) Age structure and disturbance history of a southern Appalachian virgin forest. Ecology 61: $1169-1184$

Lorimer CG, Frelich LE (1989) A methodology for estimating canopy disturbance frequency and intensity in dense temperate forests. Can J For Res 19:651-663

Lott JN, Sittel MC (1994) The February 1994 ice storm in the southeastern U.S. National Climatic Data Center (NCDC), Asheville, NC

Lott N, Graumann A, Ross D (1998) Eastern U.S. flooding and ice storm. Document from National Climatic Data Center (NCDC) Available at http://www.ncdc.noaa.gov

Loucks OL (1970) Evolution of diversity, efficiency, and community stability. Am Zool 10:17-25

Merrens EJ, Peart DR (1992) Effects of hurricane damage on individual growth and stand structure in a hardwood forest in New Hampshire, USA. J Ecol 80:787-795

Michaels PJ (1991) Bringing in the sleeze. Virginia Climate Advisory, Winter 1991 14(4):3-14

National Climatic Data Center (NCDC) (1979a) Climatological data, Vol 84. US Department of Commerce, National Oceanic and Atmospheric Administration, Asheville, NC

National Climatic Data Center (NCDC) (1979b) Storm data, Vol 21. US Department of Commerce, National Oceanic and Atmospheric Administration, Asheville, NC

National Climatic Data Center (NCDC) (1994a) Climatological data, Vol 99. US Department of Commerce, National Oceanic and Atmospheric Administration, Asheville, NC

National Climatic Data Center (NCDC) (1994b) Storm data and unusual weather phenomena with late reports and corrections, Vol 36. US Department of Commerce, National Oceanic and Atmospheric Administration, Asheville, NC

National Climatic Data Center (NCDC) (2001) Palmer Drought Severity Index: Virginia. Graphs from $\mathrm{NCDC}_{i}$ available at http://www.ncdc.noaa.gov

Nicholas NS, Zedaker SM (1989) Ice damage in spruce-fir forests of the Black Mountains, North Carolina. Can J For Res 19:1487-1491

Niklasson M, Granström A (2000) Numbers and sizes of fires: long-term spatially explicit fire history in a Swedish boreal landscape. Ecology 81:1484-1499

Pedersen BS (1998) The role of stress in the mortality of Midwestern oaks as indicated by growth prior to death. Ecology 79:79-93

Peterson CJ, Rebertus AJ (1997) Tornado damage and initial recovery in three adjacent, lowland temperate forests in Missouri. J Veg Sci 8:559-564

Phipps RL (1982) Comments on interpretation of climatic information from tree rings, eastern North America. TreeRing Bull 42:11-22

Poreh M, Mechrez E (1984) The combined effect of wind and topography on rainfall distribution. J Hydrol 72:1-23

Rauber RM, Ramamurthy MK, Tokay A (1994) Synoptic and mesoscale structure of a severe freezing rain event: the St. Valentine's day ice storm. Weather Forecast 9:183-208

Reams GA, Van Deusen PC (1996) Detection of a hurricane signal in baldcypress tree-ring chronologies. Radiocarbon 14:265-271

Reilly AE (1991) The effects of Hurricane Hugo in three trop- ical forests in the U.S. Virgin Islands. Biotropica 23: 414-418

Rhoades V (1918) Ice storms in the southern Appalachians. Mon Weather Rev 46:373-374

Richwien BA (1980) The damming effect of the southern Appalachians. Natl Weather Dig 5:2-12

Romme WH, Knight DH (1981) Fire frequency and subalpine forest succession along a topographic gradient in Wyoming. Ecology 62:319-326

Seischab FK, Bernard JM, Eberle MD (1993) Glaze storm damage to western New York forest communities. Bull Torrey Bot Club 120:64-72

Sharon D (1980) The distribution of hydrologically effective rainfall incident on sloping ground. J Hydrol 46:165-188

Smith RB (1989) Mechanisms of orographic precipitation. Met Mag 118:85-88

Spaulding P, Bratton AW (1946) Decay following glaze storm damage in woodlands of central New York. J For 44: $515-519$

Speer JH, Swetnam TW, Wickman BE, Youngblood A (2001) Changes in pandora moth outbreak dynamics during the past 622 years. Ecology 82:679-697

Stahle DW, Cleaveland MK, Hehr JG (1985) A 450-year drought reconstruction for Arkansas, United States. Nature 316:530-532

Stewart RE, King P (1987) Freezing precipitation in winter storms. Mon Weather Rev 115:1270-1279

Stokes MA, Smiley TL (1968) An introduction to tree-ring dating. University of Chicago Press, Chicago

Swetnam TW, Betancourt JL (1990) Fire-southern oscillation relations in the southwestern United States. Science 249: $1017-1020$

Swetnam TW, Lynch AM (1993) Multicentury, regional-scale patterns of western spruce budworm outbreaks. Ecol Monogr 63:399-424

Travis DJ, Meentemeyer V (1991) Influence of glaze ice storms on growth rates of loblolly pine Pinus taeda and shortleaf pine Pinus echinata in the southern Appalachian Piedmont. Clim Res 1:199-205

Travis DJ, Grissino-Mayer HD, Suckling PW (1989) The impact of ice storms on tree ring widths of loblolly pine in northern Georgia. In: Proc 6th Conference on Applied Climatology, March 7-10, 1989, Charleston, SC. American Meteorological Society, p J38-J40

Travis DJ, Meetemeyer V, Belanger RP (1990) Stressed trees produce a better climatic signal than healthy trees. TreeRing Bull 50:29-32

United States Forest Service (USFS) (1999) Indepdence Day blowdown. Document from Superior National Forest; available at http://www.snf.toofanorth.org

United States Historic Climate Network (USHCN) (1998) Data from NCDC ftp site. Available at ftp://ftp.ncdc.noaa.gov/ pub/data/USHCN/

Waring RH, Pitman GB (1985) Modifying lodgepole pine stands to change susceptibility to mountain pine beetle attack. Ecology 66:889-897

Whigham DF, Olmsted I, Cano EC, Harmon ME (1991) The impact of Hurricane Gilbert on trees, litterfall, and woody debris in a dry tropical forest in the northeastern Yucatan Peninsula. Biotropica 23:434-441

Whitney HW, Johnson WC (1984) Ice storms and forest succession in southwestern Virginia. Bull Torrey Bot Club 111:429-437

Wilkinson M (1993) Tornadoes in the lab. Knoxville News Sentinel, Monday, May 3, p B1

Williams BB (1960) The 1960 ice storm in northern Alabama. Weatherwise 13:196-199, 203

Submitted: August 2, 1999; Accepted: October 3, 2001

Proofs received from author(s): December 12, 2001 